\title{
THE ISSUES OF GREEN ECONOMY INNOVATIVENESS
}

\author{
Zbigniew BRODZIŃSKI, Department of Spatial and Environmental Economics, Faculty of Economics, University of Warmia and \\ Mazury in Olsztyn, Oczapowskiego 4, 10-719 Olsztyn, Poland; zbr@uwm.edu.pl \\ Krystyna KUROWSKA, Department of Real Estate Management and Regional Development, Faculty of Geodesy, Geospatial and \\ Civil Engineering; University of Warmia and Mazury in Olsztyn, ul. Prawocheńskiego 15, 10-720 Olsztyn, Poland. \\ krystyna.kurowska@uwm.edu.pl (corresponding author)
}

\begin{abstract}
Broadly speaking, the green economy involves pro-environmental products and services, investments, economy sectors, public procurement contracts, and jobs. This is a new idea, both in terms of regulations supporting its development and of practical effects of the implementation of technologies and organisational solutions aimed at the protection of natural environment.

The possibility for obtaining new jobs thanks to the support of the green economy is the focus of various decision-making centres. The problem, however, is the lack of a thorough understanding of the potential existing in the developing green job market, particularly in rural areas, which hampers taking efficient measures.

The aim of the study was to indicate the determinants of and opportunities for the development of the green economy and green jobs in sectors related to the rural economy. The opinions presented in the study were obtained through interviews from a randomly selected group of 578 managers of "green economy"-related businesses operating in rural areas. The study participants are entrepreneurs employing workers and creating jobs in the following areas: agri-food processing, services, manufacturing, renewable energy sources, and tourism.

It can be concluded that, inter alia, despite the difficult situation in the labour market, and the problems with sales of products and services in the green economy sector, it should be expected that in the next few (3 to 5) years, the social demand for innovative products/services of this sector will increase.
\end{abstract}

Keywords: green economy, green jobs, rural areas, sustainable development of rural areas.

\section{INTRODUCTION}

In the modern world, one of the most desirable development paradigms is the sustainable development focused on the improvement of the quality and prosperity of life at a level determined by the knowledge and resources one has. This is still a new idea which indicates the pathways of the development of civilisation and technical progress (Hopwood et al., 2005; Berdo, 2006; Gerwin, 2008; Pawłuszko, 2014).

The principle of sustainable development is enshrined in Article 5 of the Constitution of the Republic of Poland, which provides that "The Republic of Poland shall safeguard the independence and integrity of its territory and ensure the freedoms and rights of persons and citizens, the security of the citizens, safeguard the national heritage and shall ensure the protection of the natural environment pursuant to the principles of sustainable development". This Basic Law imposes the obligation to care for the state of the environment and to ensure the environmental safety to both the present and the future generations on all institutions in Poland.

The concept of balanced and sustainable development in classic terms is not only focused on the limited amount and accessibility of resources but also on the frequency of their occurrence and their spatial distribution (Łuszczyk, 2009). Here, the sustainable development is perceived in three dimensions: environmental, economic, and social (Waas et al., 2010; Sachs \& Reid, 2006). The result of many years' research including an assessment and forecasting the directions of sustainable development is the extension of the concept to include new elements (Waas et al., 2010).

In 2011, the Central Statistical Office (GUS) published a set of 76 indicators of sustainable development, which not only characterise the social, economic, and environmental order but also the institutional-and-political order as the fourth important element of sustainable development. In turn, in 2015, a set of 101 indicators was presented in a supplemented report of the GUS. Attention should also be paid to the fifth dimension of sustainable development i.e. the spatial order which has been introduced into Poland's legislation relatively recently. The spatial order is understood as an element of the assessment of land development from different angles, with the simultaneous indication of its role in the development of a particular area, and is of interest in various aspects (Cymerman et al., 2002; Parysek, 2003; MałysaSulińska, 2008; Bański, 2008).

One of the most recent interpretations of the operationalisation of sustainable development in economic practice is the concept of green economy (Dokurno et al., 2016). The green economy is an economy actively participating in the promotion of environmentally-friendly attitudes of the whole society and economic actors, supporting eco-friendly patterns 
and innovations, while maintaining a high level of economic development (Wyszkowska and Rogalewska, 2014). It should be understood as a new pathway of socio-economic development which enables the access to sustainable economy. However, it does not replace the sustainable development as its scope is much narrower (Wyszkowska and Rogalewska, 2016). Recently, mainly in economic sciences, the subject of research and analyses has been various aspects of the "green economy", including the determinants of the development of green jobs, green services, green innovations, etc.

The green economy can be seen as a more pragmatic approach to the implementation of sustainable development (Burchard-Dziubińska, 2013). According to Ryszawska (2013), the green economy strategy is simply a response to the weakness of the concept of sustainable development. This results from the lack of operationalisation and the transfer to policy in the form of specific objectives and the ways to achieve them.

The aim of the study was to indicate the determinants of and opportunities for the development of the green economy and green jobs in sectors related to the rural economy. The opinions presented in the study were obtained through interviews carried out using the CATI technique (Computer Assisted Telephone Interviewing) from a randomly selected group of 578 managers of "green economy"-related businesses operating in rural areas. The study participants are entrepreneurs employing workers and creating jobs in the following areas: agri-food processing, services, manufacturing, renewable energy sources, and tourism.

\section{THE GREEN ECONOMY AND ITS SECTORS}

The idea of green economy is focused on perceiving the hazards resulting from expansive economic and social activities of humans, which irrevocably destroy the natural environment and its limited resources. This concept is inextricably linked to the paradigm of sustainable social and economic development based on technologies that play an auxiliary role in relation to the natural environment, and on the social responsibility of business for the quality of future generations' lives (Brodziński and Brodzińska, 2016). The implementation of the green economy principles requires increasing economic efficiency, improving the quality of people's lives, carrying out awareness campaigns in the fields of ecology, and the common acceptance of the primacy of environmental protection over achieving short-term benefits, which can result from the non-compliance with them (Byczkowska-Ślęzak et al., 2012, p. 26). The green economy embraces practically all areas of human activities that affect the natural environment in any way. It has been adopted in the source literature that the development of green economy is based on the transformation of ten key sectors, including agriculture, construction, energy, fisheries, forestry, energy-efficient industry, tourism, transport, waste management, and water resources management (Byczkowska-Ślęzak et al., 2012, p. 32). According to the OECD, green growth involves supporting economic growth and development while ensuring that the nature continues to provide environmental resources and services which determine the humans' prosperity. The governments which pursue an active policy based on green growth must stimulate such investments and innovations that can provide a basis for growth, and create new economic opportunities (Green Growth Indicators, 2017). The development of green economy is aimed at achieving such objectives as (Green economy..., 2013, p. 7):

- increasing energy and resource efficiency,

- reducing greenhouse gas emissions (particularly carbon dioxide),

- reducing the level of contaminants generated from manufacturing processes,

- increasing energy security,

- mobilising the use of innovation potential,

- gaining new competitive advantages.

Therefore, the development of the green economy is linked to numerous processes taking place in enterprises as well as in the public administration. The above-mentioned processes are primarily based on an economic policy that promotes stimulating activities in research and development, which is the fundamental factor in protecting the natural environment. Therefore, with the implementation of new solutions stimulating the economic development, a need emerged to develop measures of progress in the process of "greening" the economy (Wyszkowska and Rogalewska, 2016). An important element is the examination of the effects of green economy in relation to the development of economic growth, and of the results of shaping the balanced and sustainable development, while taking into account the pragmatic dimension of the green economy (Szyja, 2014). In Poland, the key factors of green growth include inter alia: (GUS, 2015):

1. Expenditures on the environmental protection aimed at reducing the adverse effects of humans' activities on the environment through capital expenditures in the form of expenditures on fixed assets used to generate a material basis to protect the environment.

2. The research and development (R\&D) supporting the "greening" of economy, and an increase in innovativeness and competitiveness of enterprises operating in this sector.

3. Inventions in the field of environmental protection technologies, which enable the reasonable use of natural resources, reduce the adverse effects of manufacturing and services on the environment, and can also lead to the creation of new products, jobs, improvement of technologies, and consequently to an increase in the competitiveness of economy, or tangible economic benefits in the form of e.g. savings on materials, energy, or costs related to environmental charges (Kaźmierczak-Piwko, 2012).

4. Eco-innovations contributing to an increase in efficiency of the use of resources in economy, and to a reduction in the adverse effects of humans' activities on the environment.

5. Green public procurement contracts which are a tool for incorporating environmental criteria and/on requirements into procedures for awarding public procurement contracts, which can actually contribute to reducing the adverse 
effects of products and services on the natural environment.

The issue of distinguishing which of the economy sectors are related to the green sector can be considered from both a broader and narrower perspective. In principle, it can be considered that in nearly all sections of the Polish Classification of Activity (PKD) $2007^{1}$, there are a number of activities more or less directly associated with environmental protection. However, the sectors directly related to the green economy are as follows:

- agriculture, forestry, hunting, and fisheries,

- industrial processing,

- generation and supply of electricity, gas, steam, hot water, and the air to air-conditioning systems,

- water supply; sewage and waste management, and reclamation-related activities,

- construction,

- wholesale and retail trade; repair of motor vehicles,

- transport and warehouse management,

- activities related to accommodation and catering services,

- activities in the field of administration services, and supporting activities,

- public administration and national defence; compulsory social security.

Most frequently, the study participants represented the sector of services (72.2\%). Fewer of them represented enterprises operating in the field of manufacturing (19.0\%) and tourism (6.0\%), while the smallest group comprised representatives of entities of the agri-food processing sector $(2.2 \%)$ and renewable energy sources $(0.6 \%)$. $42.4 \%$ of entities only provided services, further $24.0 \%$ are entities operating in the services and trade sectors, while $12.3 \%$ of enterprises provided services and, at the same time, manufactured goods. The most complex activities were pursued by $7.1 \%$ of enterprises whose scope of economic activity included not only services but also trade and manufacturing.

A characteristic feature of an enterprise participating in the study is the structure of enterprise size classes in terms of the number of employees. In the study, the representatives of micro-firms employing up to 9 workers (73.7\%) and of small firms employing from 10 to 49 workers (20.4\%) were dominant. A significantly smaller group comprised entrepreneurs representing medium firms employing from 50 to 249 workers (4.3\%), and large firms giving employment to 250 and more workers $(1.6 \%)$.

In the structure of ownership forms of the enterprises participating in the study, the largest group comprised natural persons pursuing economic activities (78.5\%). The group of entities representing companies, including limited liability companies $(15 / 1 \%)$, civil law partnerships (3.6\%), and general partnerships $(2.8 \%)$, was smaller.

\section{INNOVATIVENESS OF THE GREEN SECTOR}

Innovativeness of the green economy is closely linked to the effects of scientific research aimed at the development of technical and technological innovations reducing the pressure of the economic activities pursued so far on the natural environment, and to the raising of environmental awareness among workers and entire communities (Kozar, 2016). The process of economic changes aimed at increasing the resource efficiency, improving efficiency, and minimising the adverse effects of economic activities on the natural environment requires appropriate financial expenditures on research and development as well as time. On the one hand, it is the time needed for the development of pro-environmental technologies, and on the other, for the rearrangement of priorities resulting in the environmental protection being equal to an enterprise's financial result. The relatively low expenditures on research and development in Poland is accompanied by a low level of innovativeness of the economy (Table 1 ).

It is worth paying attention to the large spatial differentiation of the level of the economy innovativeness. As it has been observed, the general trend in the enterprises under study was the passivity in the area of the implementation of innovations, since as many as $78.4 \%$ of enterprises have introduced no innovative solutions (Fig. 1). The low level of innovativeness of the enterprises included in the "green economy" category may indicate their traditional approach to the issue of resource management, or their low competitive position in this regard. It is also worth stressing that in the future it can lead to widening the gap in the development of the green economy in particular regions of the country. The selected projects co-financed by the OP Innovative Economy funds (co-financing of innovative projects) indicate the spatial differentiation of the capacity for developing innovative solutions in the area of the green economy. In this regard, Śląskie and Zachodniopomorskie Voivodeships stand out, which is also confirmed by results of other authors' studies (Plac, 2016).

Having considered all enterprises which declared the implementation of innovations, product innovations understood as the introduction of a new product or service, or their significant improvement in relation to the characteristics or the intended use (including a significant improvement in the field of technical specification, components and materials of the accompanying software, the "friendliness" towards the user, and functionalities), were dominant (10.5\%). Own research confirms the opinion expressed inter alia by Krawiec (2001), according to which the driving forces behind the process of introduction of product innovations include:

- the worldwide development of the technological base and know-how,

- the changing needs, expectations, and preferences of customers,

${ }^{1}$ Polish Classification of Activities (PKD) 2007: http://stat.gov.pl/Klasyfikacje/doc/pkd_07/pkd_07.htm (accessed on: 14 August 2017). 
- the gradual reducing the life cycle of products, being a consequence of technological changes and market requirements,

- open foreign markets, and increasing competition on the global scale.

Table 1. Expenditures on research and development per capita in selected EU countries (in USD)

\begin{tabular}{|c|c|c|c|c|c|c|}
\hline \multirow{2}{*}{ Country } & 2010 & 2011 & 2012 & 2013 & 2014 & 2015 \\
\hline & \multicolumn{6}{|c|}{ USD per capita } \\
\hline Sweden & 1340 & 1422 & 1468 & 1511 & 1461 & 1561 \\
\hline Austria & 1148 & 1187 & 1355 & 1418 & 1487 & 1520 \\
\hline Denmark & 1257 & 1308 & 1336 & 1390 & 1397 & 1451 \\
\hline Germany & 1085 & 1194 & 1250 & 1277 & 1360 & 1381 \\
\hline Luxembourg & 1288 & 1343 & 1165 & 1242 & 1280 & 1339 \\
\hline Finland & 1446 & 1480 & 1389 & 1359 & 1317 & 1226 \\
\hline Belgium & 824 & 895 & 1007 & 1067 & 1110 & 1127 \\
\hline The Netherlands & 769 & 877 & 906 & 951 & 982 & 1000 \\
\hline France & 784 & 821 & 840 & 886 & 900 & 915 \\
\hline The United Kingdom & 599 & 613 & 604 & 649 & 684 & 711 \\
\hline Slovenia & 572 & 698 & 744 & 770 & 740 & 708 \\
\hline The Czech Republic & 369 & 448 & 518 & 580 & 639 & 658 \\
\hline Italy & 425 & 435 & 454 & 470 & 499 & 496 \\
\hline Estonia & 342 & 565 & 551 & 473 & 414 & 434 \\
\hline Spain & 432 & 425 & 412 & 414 & 417 & 425 \\
\hline Portugal & 419 & 390 & 365 & 370 & 372 & 379 \\
\hline Hungary & 246 & 272 & 292 & 340 & 347 & 365 \\
\hline Slovakia & 153 & 171 & 215 & 230 & 256 & 353 \\
\hline Poland & 150 & 168 & 207 & 213 & 239 & 267 \\
\hline Greece & 169 & 176 & 177 & 212 & 221 & 252 \\
\hline Latvia & 108 & 138 & 141 & 139 & 165 & 156 \\
\hline Romania & 75 & 86 & 87 & 73 & 76 & 102 \\
\hline Ireland & 690 & 701 & 724 & 754 & 776 & $\begin{array}{c}\text { no data } \\
\text { available }\end{array}$ \\
\hline
\end{tabular}

Source: developed on the basis of: Nauka. Spoleczeństwo informacyjne. Innowacyjność, http://stat.gov.pl/statystyka-miedzynarodowa/porownaniamiedzynarodowe/tablice-o-krajach-wedlug-tematow/nauka-spoleczenstwo-informacyjne-innowacyjnosc/ (accessed on 28/08/2017)

firma/instytucja/organizacja nie wprowadziła innowacji

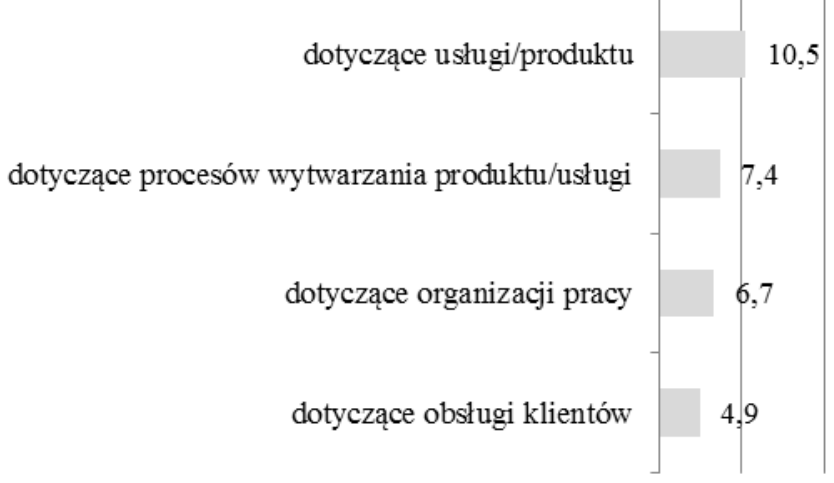

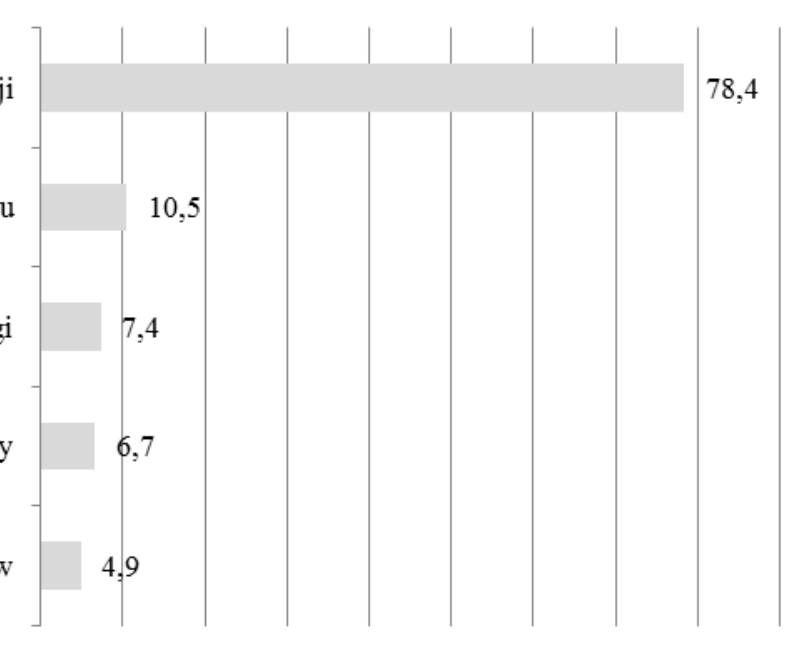

Source: own research.

Figure 1. Types of innovations introduced by the enterprises under study $(\%)$

Innovations in the processes of manufacturing a product/service, understood as the introduction of new methods for manufacturing or supplies, or their significant improvement (including changes in technologies, equipment and/or software), have been introduced by $7.4 \%$ of enterprises under study (Fig. 1). Process innovations are equally important as product innovations, and are most frequently introduced in order to reduce the costs of manufacture of supplies, 
increase the quality, increase the efficiency of manufacturing, and supply new or significantly improved products. Their implementation increases an enterprise's efficiency and results in the final product being cheaper, and consequently allows the enterprise to join the group of the best firms, and to be more competitive.

The carried out study demonstrates that organisational innovations defined as the introduction of new ways to organise the activities of an enterprise, to organise workplaces, or to develop relationship with the environment have been introduced by $6.7 \%$ enterprises (Fig. 1). It is worth stressing that for a long time, in professional circles associated with innovations, there was a strong belief that innovations in the field of techniques and technologies were more important to the development of an enterprise. On the other hand, organisational innovations used to be regarded as a certain additional element or as a solution ensuring the adaptation of technical and technological innovations in an enterprise. In recent years, entrepreneurs' approaches towards such innovations have changed, and now innovations in the field of organisational structures are also regarded as a significant source of an increase in the efficiency of an enterprise's functioning. This largely applies to firms in the SME sector, which can see the opportunities for development in lowinput organisational innovations (Lachiewicz, 2014).

The category of innovations in the field of customer service has also been included in the area of researchers' interest. Innovations in this regard help provide customers with the best possible services. Innovations of this type include e.g. multi-media spots for children, a sign language translator, free Wi-Fi spots, beverages, and other ways to increase the quality of services. The study results demonstrated that innovations in the field of customer service have only been introduced by $4.9 \%$ of enterprises (Fig. 1).

The observed trend for a low level of activity in the implementation of innovations by all green economy enterprises concerned, in principle, all enterprises operating in rural areas. The percentage of enterprises under study which have failed to engage in activities related to the implementation of innovations ranged from $64.2 \%$ in production enterprises to $80.2 \%$ in service-providing enterprises (Table 2).

Table 2. Types of introduced innovations, divided by the areas of enterprises' economic activity, in respondents' opinions

\begin{tabular}{l|r|r|r|r|r}
\multicolumn{1}{c|}{ Specification } & agri-food processing & services & manufacturing & $\begin{array}{r}\text { renewable } \\
\text { energy sources }\end{array}$ & tourism \\
\hline Service/product innovations & 14.3 & 8.8 & 18.3 & 0.0 & 12.8 \\
\hline $\begin{array}{l}\text { Innovations in processes of a } \\
\text { product/service manufacturing }\end{array}$ & 14.3 & 5.2 & 20.0 & 25.0 & 7.7 \\
\hline Innovations in work organisation & 0.0 & 7.3 & 5.8 & 0.0 & 5.1 \\
\hline Innovations in customer service & 0.0 & 4.9 & 6.7 & 0.0 & 5.1 \\
\hline $\begin{array}{l}\text { A firm/institution/organisation has not } \\
\text { introduced innovations }\end{array}$ & 78.6 & 80.2 & 64.2 & 75.0 & 79.5 \\
\hline
\end{tabular}

Production enterprises, including a group of entities manufacturing e.g. wooden article, furniture, boilers, etc., in which $35.8 \%$ have implemented innovations, were characterised by the highest level of innovativeness ${ }^{2}$. Most frequently, these are innovations in the field of modernisation of the processes of product manufacturing, which have been implemented in every fifth firm under study. Innovations in this field primarily include new or significantly improved manufacturing technologies. Production enterprises under study have invested in process innovations slightly more frequently than in product innovations. Product innovations have been introduced by $18.3 \%$ of the representatives of this group. The smallest group was that comprising production enterprises which have introduced innovations in the field of customer services $(6.7 \%)$ and work organisation $(5.8 \%)$ (Table 2$)$.

The second place in the ranking was taken by enterprises in the renewable energy sources sector, in which every fourth entity has implemented innovative solutions in the area of processes of a product/service manufacturing. As regards the RSE, process innovations appear to be the crucial ones, and this is not so much about the improvement of production efficiency but about the functional systems of its storage. This is because the RSE are the least stable energy sources, and this is the possible breaks in energy supply that is the biggest problem of this sector as regards the dissemination of renewable energy.

In the enterprises under study, representing the agri-food processing sector, innovative solution have been implemented by only $21.4 \%$ of business entities, whereas they concerned, to the same extent, product innovations and process innovations (14.3\% of responses for each of them) (Table 2). The results of the carried out study do not enable a complete assessment of the innovativeness of these products on the global scale. Given that Polish food enterprises are characterised by a rather low level of innovativeness, they are not familiar with the creation of on original and modern range of products (Kaczorowska, 2009), and product innovations in this sector are rather created in accordance with the trends typical of the developed countries. Increasing the activity of Polish food sector enterprises in the area of innovative product-related activities should focus on the creation of products adjusted to the needs of modern consumers. This primarily refers to "healthy" products, attractive in terms of sensory characteristics, and convenient, of good quality, and sold for an affordable price. The competitive advantage in the agri-food processing sector worldwide could be primarily gained by original products being a result of creative ideas of Polish entrepreneurs.

\footnotetext{
${ }^{2}$ an entity frequently declared the implementation of more than one type of innovations.
} 
As follows from the carried out study, innovative solutions on the tourism sector have been implemented by $20.5 \%$ of enterprises. Most frequently, the introduced changes are associated with product innovations (12.8\%), and less frequently with process innovations in relation to the service provided (7.7\%). To a small extent, they concerned modern solutions in the field of work organisation (5.4\%) and customer service $(5.1 \%)$ (Table 2). From the tourism sector perspective, strong competition and the need to adjust firms to the changing conditions and to tourists' demand require that frequent innovative measures be taken. At the same time, it must be stressed that an important aspect of innovations as a factor of competitiveness is their social usefulness, and thus the increasingly better satisfying the needs and expectations of a modern tourist, and achieving better efficiency of tourism activities (Mielcarek and Szalczyk, 2013).

The level of innovativeness of service enterprises was similar to that of the tourism sector, and was $19.8 \%$. Most frequently, enterprises in this sector have introduced innovations in the field of a new service, as a product $(8.8 \%)$, and work organisation $(7.3 \%)$. Few enterprises have introduced innovations in the processes of service provision $(5.2 \%)$ and customer service $(4.9 \%)$ (Table 2). The innovation activity of service enterprises is closely linked to their form of ownership, size, and the sector. Innovations are introduced more intensely by large enterprises in the public sector, which employ qualified personnel and pursuing activity in which the development of information and communication technologies facilitates the absorption of knowledge and strengthens the innovation potential. In enterprises of this type, the intensity of competition is high, and customers become participants of the processes of creating and implementing innovations, which thus determines their market success (Czubała, 2015). Since the study involved firms located in rural area, the low level of innovativeness of service firms can be a result of their specificity. This is because the insurance, reinsurance, financial, telecommunications, and IT services which are characterised by high innovativeness are most frequently located in cities.

The low level of innovativeness of green economy enterprises operating in rural areas should be regarded as a barrier to the development of local labour markets. This primarily results from the failure to use the innovation potential of enterprises. Innovative enterprises stimulate the economic development. Through the investment processes, they strengthen their position in the market, and an increase in sales of goods and services can certainly contribute to the quantitative and qualitative increase in the number of created new jobs (Węgrzyn, 2013).

\section{Conclusions}

The modern economy is characterised by the increased significance of innovations as a factor determining the development of regions. Product innovations (new, better, more attractive products and services addressed at a consumer) enable the achievement of a larger share in the market, and gaining a competitive advantage. Process innovations introduce new technological solutions, thus contributing to an improvement in the profitability of production thanks to, inter alia, the reduction in costs and in the improvement of efficiency. The increase in the effectiveness of enterprises' functioning is also contributed to by organisational innovations, while innovations in the field of customer service are a tool which is just necessary in order to maintain a firm's position in the market under the conditions of strong competition. In this context, a low level of innovativeness of the entities under study, operating in rural areas, certainly does not contribute to the development of the green economy sector. At the moment, it is difficult to indicate an optimum strategy for the development of entities included in the category of the so-called "green sector", whereas particular attention should be paid to the support of actions aimed at increasing their innovativeness and competitiveness.

While considering the innovativeness of the green economy in rural areas, account should be taken of the so-called contextual determinants which significantly affect an enterprise's capacity for pursuing innovative activities including inter alia spatial, environmental, and demographic determinants as well as those related to economic activity of the population.

\section{ACKNOWLEDGEMENT}

The publication has been drawn up as part of the operation called "Perspektywy rozwoju zielonych miejsc pracy" ( Prospects for the Development of Green Jobs'), co-financed with European Union funds under the Technical Assistance (RDP 2014-2020), European Agricultural Fund for Rural Development: Europe investing in rural areas (No 22.690.032).

\section{REFERENCES}

1. Bański, J. 2008. Lad przestrzenny obszarów wiejskich ze szczególnym uwzględnieniem oddziaływania gospodarki rolnej ekspertyza przygotowana na zlecenie. Instytutu Ekonomiki Rolnictwa i Gospodarki Żywnościowej - Państwowego Instytutu Badawczego, Warszawa, pp. 6-7. [In Polish]

2. Berdo, J. 2006. Zrównoważony rozwój. W stronę życia w harmonii z przyrodą. Earth Conservation. Sopot. p. 101. [In Polish]

3. Brodziński, Z., Brodzińska, K. 2016. Uwarunkowania rozwoju rynku zielonych miejsc pracy na przykładzie podmiotów zajmujących się przetwórstwem biomasy na cele energetyczne. [Conditions of Green Jobs Market Development Based on the Example of Businesses Processing Biomass for Energy Purposes]. Prace Naukowe Uniwersytetu Ekonomicznego we Wroctawiu [Research Papers of Wroctaw University of Economics], No 454, pp. 22-30. [In Polish]

4. Burchard-Dziubińska, M. 2013. Zielona gospodarka jako nowy obszar zainteresowania ekonomii. Referat na IX Kongres Ekonomistów Polskich nt.: Ekonomia dla przyszłości. Odkrywać naturę i przyczyny zjawisk gospodarczych, Warszawa. [In Polish]

5. Byczkowska-Ślęzak, J., Dolińska-Szwarc, A., Tomczyk, U., Toczyński, T., Raźniewski, P. 2012. Analiza zielonego rynku pracy w województwie podlaskim. [ed.] D. Śledź, Wojewódzki Urząd Pracy w Białymstoku, Białystok. p. 26. [In Polish]

6. Constitution of the Republic of Poland from April 2, 1997 (Journal of Laws of 1997, no 78, item 483). 
7. Cymerman R., Fiedorowicz-Kozłowska E., Podciborski T., 2002. Ład przestrzenny podstawą rozwoju obszarów wiejskich, Inżynieria Ekonomiczna, No. 6, pp. 85-92. [In Polish]

8. Czubała A. 2015. Innowacje w sektorze usług w Polsce [Innovations in the service sector in Poland]. Zeszyty Naukowe MWSE $w$ Tarnowie, Vol. 1 (26), pp. 35-45. [In Polish]

9. Dokurno Z., Fiedor B., Scheuer B. 2016. Makroekonomiczna i metodologiczna perspektywa dyskursu wokół pojęcia zielonej gospodarki [The discourse on the green economy from macroeconomic and methodological perspective]. Gospodarka Narodowa, Vol. 1, pp. 5-28.

10. Gerwin M. 2008. Plan zrównoważonego rozwoju dla Polski. Lokalne inicjatywy rozwojowe. Earth Conservation, Sopot. [In Polish]

11. Green economy in der Praxis. Erfolgsbeispieleaus deutschen Unternehmen. 2013. Bundesministerium für Umwelt, Naturschutz und Reaktorsicherheit, Bundesverband der Deutschen Industrie e.V., Berlin. [In Geramn]

12. Green Growth Indicators 2017. OECD Publishing, Paris 2017. p. 162.

13. GUS. 2015. Wskaźniki zrównoważonego rozwoju Polski 2015. [Sustainable Development Indicators for Poland 2015], Urząd Statystyczny w Katowicach, Warszawa. [In Polish]

14. Hopwood, B., Mellor, M., O'Brien, G. 2005. Sustainable development: mapping different approaches. Sustainable Development, No. 13, pp. 38-52. https://doi.org/10.1002/sd.244

15. Kaczorowska, J. 2009. Innowacyjna działalność produktowa polskich przedsiębiorstw przemysłu spożywczego. [Product innovation activities in the Polish food industry] Zeszyty Naukowe SGGW Problemy Rolnictwa Światowego, Vol. 7 (22), pp. 50-57

16. Kaźmierczak-Piwko, L. 2012. Determinanty działalności ekoinnowacyjnej przedsiębiorstw [Determinants of the eco-innovative activity of companies] Zarzadzanie i Finanse, Vol. 10 (1), pp. 533-543.

17. Kozar, Ł. 2016. „Zielone” miejsca pracy w ujęciu sektorowym gospodarki. [in:] Ekonomia zrównoważonego rozwoju. Społeczeństwo, Środowisko, Innowacje w gospodarce. (eds.) R. Dziuba, M. Szewczyk, E. Okraszewska, Wydawnictwo Uniwersytetu Łódzkiego, Łódź. https://doi.org/10.18778/8088-490-8.06 [In Polish]

18. Krawiec, F. 2001. Zarządzanie projektem innowacyjnym produktu i usługi. Wydawnictwo Difin, Warszawa. [In Polish]

19. Lachiewicz, S. 2014. Innowacje organizacyjne w małych i średnich przedsiębiorstwach. [Organizational Innovations in Small and Medium Enterprises] Studia Ekonomiczne, Vo. 183, pp. 153-161. [In Polish]

20. Łuszczyk, M. 2009. Koncepcja rozwoju zrównoważonego w polityce ekologicznej państwa. [w:] D. Kiełczewski, B. Dobrzańska (red.) Ekologiczne problemy zrównoważonego rozwoju. Wydawnictwo Wyższej Szkoły Ekonomicznej w Białymstoku, pp. 49-60. [In Polish]

21. Małysa-Sulińska K. 2008. Normy kształtujące ład przestrzenny. [Standards forming the spatial order.] Oficyna Wolters Kluwer Business, Warszawa.

22. Mielcarek, B., Szalczyk, A. 2013. Innowacje jako czynnik konkurencyjności sektora turystycznego w warunkach globalizacji. [in:] Współczesne uwarunkowania i problemy rozwoju turystyki. R. Pawlusiński (ed.), IGiGP UJ, Kraków, pp. 199-206. [In Polish]

23. Parysek J. J. 2003. Ład przestrzenny jako kategoria pojęciowa i planistyczna, [in:] Społeczno-gospodarcze i przyrodnicze aspekty ładu przestrzennego, (eds.) T. Ślężak, Z. Zioło, Warszawa. „Biuletyn KPZK PAN” z. 205. [In Polish]

24. Pawłuszko T. 2014. Strategia zrównoważonego rozwoju w dokumentach Nordyckiej Rady Ministrów. [in:] Dyplomacja w życiu. Życie w dyplomacji, W. Saletra, J. Jaskiernia, R. Kubicki (red.), Wydawnictwo UJK, p. 285-299. [In Polish]

25. Plac, K. 2016. Regionalne zróżnicowania w zakresie wsparcia zielonej ekonomii z funduszy europejskich w latach 2007-2013 [Regional differences in supporting the green economy by the EU funds in the years 2007-2013]. Prace Naukowe Uniwersytetu Ekonomicznego we Wroctawiu, No.433, p. 161. [In Polish]

26. Ryszawska, B. 2013. Zielona gospodarka - teoretyczne podstawy koncepcji i pomiar jej wdrażania w Unii Europejskiej, Wydawnictwo Uniwersytetu Ekonomicznego we Wrocławiu, Wrocław. [In Polish]

27. Sachs J.D., Reid W.V. 2006. Investment Toward Sustainable Development. Policy Forum. Environmental Science, vol. 12, No 5776, p. 1002. https://doi.org/10.1126/science.1124822

28. Szyja P. 2014. Rola wskaźników zrównoważonego i trwałego rozwoju w badaniu zielonej gospodarki [Role of Indicators for Sustainable Development in Research into Green Economy] Optimum. Studia Ekonomiczne, Vol. 4 (70), pp. 61-76. https://doi.org/10.15290/ose.2014.04.70.05 [In Polish]

29. Waas, T., Verbruggen, A., Wright, T. 2010. University research for sustainable development: definition and characteristics explored. Journal of Cleaner Production, No. 18, pp. 629-636. https://doi.org/10.1016/j.jclepro.2009.09.017

30. Węgrzyn, G. 2013. Innowacje jako determinanta zmian strukturalnych rynku pracy. [Innovation As a Determiner of Structural Changes in the Labour Market]. Studia Ekonomiczne Uniwersytetu Ekonomicznego w Katowicach, Katowice, 145, pp. $209-219$.

31. Wyszkowska, D., Rogalewska, A. 2014. Monitorowanie zielonej gospodarki w ujęciu organizacji międzynarodowych [Monitoring of green economy: international experience]. Optimum Studia Ekonomiczne, Vol. 3 (69), pp. 32-51, http://hdl.handle.net/11320/2603 . . [In Polish]

32. Wyszkowska D., Rogalewska A. 2016. Wskaźniki zielonej gospodarki dla Polski oraz pozostałych krajów Unii Europejskiej [Green economy indicators for Poland and other European Union countries]. Wiadomości Statystyczne, Vol. 10, pp. 54-74. . [In Polish] 